Brit. J. industr. Med., 1957, 14, 177.

\title{
A STUDY OF THE THERMAL ENVIRONMENT IN NON-FERROUS FOUNDRIES
}

\author{
BY \\ D. TURNER \\ From the Medical Research Council Environmental Hygiene Research Unit, Hampstead, London
}

(RECEIVED FOR PUBLICATION MARCH 27, 1957)

Foundries where non-ferrous metals are cast are often very hot and it is not uncommon in the height of summer for a foundry to be closed shortly after midday because conditions become too hot for sustained work. This survey of typical working environments in such foundries was made at the request of a Joint Standing Committee of the Ministry of Labour and National Service consisting of representatives of the employers and trade unions concerned, which was charged with studying safety, health, and welfare in non-ferrous foundries.

The work done in these foundries fell into two main categories; in the first were tasks which involved only short exposures to intense heat, while in the second were tasks involving exposure to a hot environment continuously throughout the shift. The results of this survey show that it was only possible by the standard methods to measure very roughly the exposure in the former category of work but that a more accurate assessment could be made of the severity of the heat stress in the latter division.

From the observations made in this study it has been possible to indicate the main features which gave rise to the uncomfortably warm environments. A furnace was subsequently designed in which many of these undesirable features were omitted, with the result that working conditions were much improved and the efficiency of the use of fuel was increased markedly.

\section{Methods of Measurement}

Surveys of the thermal environment in positions typically occupied by foundrymen were made, the values of the various thermal factors being measured.

Air temperatures were measured with an aspirated hygrometer, the bulbs of which were shielded from the influence of radiation by polished metal tubes.

The air speed was measured with a silvered katathermometer.

The intensity of radiation, expressed as the mean radiant temperature (M.R.T.), was measured both with a globe thermometer and with a thermopile, but the value obtained with the thermopile was used in preference to that calculated from the reading of the globe thermometer because the elevation of the mean radiant temperature was due largely to a few local sources of high intensity rather than to a generally high temperature of the solid surroundings. In order to scan as nearly as possible a complete sphere round the point of measurement 76 individual readings in different directions were taken with the thermopile and the mean radiant temperature was calculated from the average value. Use of the thermopile also enabled the main sources of radiant heat to be located, and gave a quantitative indication of their relative severities at the point of measurement.

\section{Results}

(1) Short Exposures.-Foundrymen in charge of the larger furnaces, mostly the rotary or tilting type of melting furnace, spent much of their time some distance from the furnace waiting for a charge of metal to be melted. Thus, although the environment near to these furnaces was hot, especially when metal was being loaded into or poured from the furnace, the men were only exposed to such conditions for a relatively short time at infrequent intervals, usually of the order of a few minutes in each hour. Much of the heat in the environs of these furnaces emanated from the considerable volumes of flue-gas which were discharged directly into the air of the foundry, and from the furnaces themselves which were inadequately insulated. In Table 1 are listed some typical environments near furnaces of these types.

The intensity of radiation to which the furnaceman was exposed increased greatly when the furnace door was opened. An indication of the extent of this increase is given in the last two examples in Table 1. The last example in this table concerns the thermal conditions near a tilting furnace from which molten metal was poured into ingot moulds on a conveyor belt. While the metal was being melted conditions were typical of those cited earlier in the 
TABLE 1

THERMAL ENVIRONMENTS NEAR TILTING AND ROTARY FURNACES

\begin{tabular}{|c|c|c|c|c|}
\hline \multirow[b]{2}{*}{ Position } & \multirow{2}{*}{$\underset{\left({ }^{\circ} \mathbf{F} .\right)}{\text { M.R.T. }}$} & \multicolumn{2}{|c|}{ Air Temperature } & \multirow{2}{*}{$\begin{array}{l}\text { Air Speed } \\
\text { (ft./min.) }\end{array}$} \\
\hline & & $\begin{array}{c}\text { Dry Bulb } \\
\left({ }^{\circ} \mathbf{F} .\right)\end{array}$ & $\begin{array}{l}\text { Wet Bulb } \\
\left({ }^{\circ} \mathrm{F} .\right)\end{array}$ & \\
\hline $\begin{array}{l}\text { In front of two tilting furnaces } \\
\text { In front of a tilting furnace } \\
\text { In front of a tilting furnace } \\
\text { In front of two tilting furnaces } \\
\text { In front of semi-rotary furnace } \\
\text { In front of same semi-rotary furnace while charging with metal } \\
\text { Beside furnaceman while pouring ingots from tilting furnace }\end{array}$ & $\begin{array}{r}106 \\
99 \\
115 \\
104 \\
66 \\
99 \\
140\end{array}$ & $\begin{array}{l}79 \\
72 \\
79 \\
79 \\
63 \\
63 \\
82\end{array}$ & $\begin{array}{l}66 \\
61 \\
62 \\
59 \\
54 \\
54 \\
61\end{array}$ & $\begin{array}{l}95 \\
\text { No record } \\
70 \\
215 \\
110 \\
110 \\
185\end{array}$ \\
\hline
\end{tabular}

table, but a rapid survey of the conditions when metal was being poured showed that there was a marked rise in the mean radiant temperature (from about $100^{\circ} \mathrm{F}$. to $140^{\circ} \mathrm{F}$.) due to considerable radiation from the molten metal and the previously cast ingots on the conveyor. This increased radiation fell on the front of the furnaceman giving rise to acute discomfort.

Whereas the capacity of most of the furnaces seen was only 600 to 800 pounds, the semi-rotary furnace referred to in Table 1 was of about 6 tons capacity. The designers had endeavoured to reduce the heat losses to the environment as much as possible, (a) by adequate insulation, so that the surface temperature remained very low, and (b) by conducting away the exhaust flue-gases in insulated ducts which discharged outside the foundry. Table 1 shows that while the furnace was closed the environment was relatively cool. Because of its large capacity this furnace took much longer to load than the smaller ones, so that a more precise measurement of the change in the mean radiant temperature while the furnace was open could be made. Surveys with the thermopile revealed that only six of the 76 readings taken changed when the furnace was open, yet this caused the mean radiant temperature to increase from $66^{\circ}$ to $99^{\circ} \mathrm{F}$. Assuming that the radiation intensity indicated by the mean of these six readings is a fair measure of the intensity of the radiation incident on the front of the man as he faced the furnace, it may be calculated that after the furnace door was opened the average intensity increased from about 146 to 570 B.Th.U./ft. $2 /$ hr., while the intensity on the line normal to the opening was about 1,550 B.Th.U./ft. ${ }^{2} / \mathrm{hr}$. So expressed the increased local exposure is shown to be much greater than the change in the mean radiant temperature would indicate.

(2) Long Exposures.-Some foundry workers, of whom those engaged in die casting formed the majority, spent almost the entire shift in the same environment. Die casters ladled molten metal from a bale-out furnace and poured it into a die. The dies were of two types, gravity dies into which the metal was poured directly from the ladle, and pressure dies into which the metal was injected under pressure after being poured by hand into the inlet. The gravity dies became very hot and were one of the sources of local, intense, thermal radiation. The radiation reaching the men from the pressure dies was less intense because the hot dies were screened by the pressure mechanism. When the metal had been in the die for a few moments and had solidified, the die was opened, the hot casting was removed, the die was re-assembled and a fresh cycle of operations was then started. A complete cycle took from one to five minutes depending upon the size of the casting and the intricacy of the die, and considerable muscular effort was involved in the work, particularly with the larger castings, for then up to about $10 \mathrm{lb}$. of metal had to be carried in the ladle and some of the individual sections of the die were relatively heavy.

Since the work was repetitive and of long duration it was possible to make more thorough assessments of the thermal environment than with the shorter exposures referred to in previous paragraphs.

In the conventional type of bale-out furnace studied in this investigation gas or oil was used as fuel. The metal to be melted was contained in a crucible which was situated in a cylindrical furnace. The fuel was supplied to a burner at the base of the furnace and burnt in the space between the furnace walls and the crucible, the metal being heated indirectly through the crucible walls. The top of the crucible was exposed, and molten metal was obtained by dipping a long-handled ladle into the crucible. A flue pipe at the back of the furnace discharged the flue-gases directly into the atmosphere at about $4 \mathrm{ft}$. from the floor. In order to obtain a sufficiently high rate of melting, and also to maintain a reducing atmosphere round the crucible which would suffer a decrease in thermal conductivity if allowed to oxidize, it was common practice to allow a tip of flame to protrude from the flue pipe.

Obviously, such a furnace was thermally inefficient. A great deal of heat was lost to the environment 
in the form of convected heat from the flue-gases, and radiant heat both from the exposed surface of the molten metal and from the furnace body. The insulation round the furnace was often inadequate and surface temperatures of about $300^{\circ} \mathrm{F}$. were not uncommon. A test of the thermal efficiency of one such furnace showed that only $13 \%$ of the calorific content of the fuel supplied was used in heating the metal. In addition to the products of combustion further atmospheric pollution was caused by the fumes which resulted from the use of fluxes from time to time in order to remove oxides and other impurities from the metal in the form of a slag. The results of surveys made in typical working positions near to such furnaces are given in Table 2.

Another type of bale-out furnace, which was in less common use because of its greater capital cost and more complicated installation, was the lowfrequency induction type of electrical furnace. Heat was generated by eddy currents set up in a column of metal by an alternating electrical field induced by coils round the column. Thus heat was produced where it was required, in the metal itself, and was not applied indirectly through a crucible. The thermal efficiency of these furnaces was much greater than that of the crucible furnace. There was little convective heating since there were no fluegases; the thermal insulation round the furnace was adequate, for example, the temperature of the outer surface was found to be of the order of $140^{\circ} \mathrm{F}$. Furthermore, the production of fumes was much reduced since comparatively little use of flux was necessary. The L.F. electric furnace, near which the environmental survey reported in Table 2 was made, was one of a group of furnaces which had been installed in the workshop in which the castings were " finished". No additional ventilation had been necessary to maintain acceptable working conditions throughout the workshop, since the furnaces emitted negligible quantities of heat and fumes. The conventional type of bale-out furnace referred to previously had invariably been installed in separate foundry shops, and typical thermal conditions in such shops are shown in the upper part of Table 2.

By far the greatest source of heat loss from the electric furnaces was the radiation from the surface of the molten metal, and, by fitting insulated sliding covers over the bath which contained the metal, this had been limited to the relatively short periods during which metal was being withdrawn from the furnace. The metal was automatically uncovered by a mechanism actuated by a foot switch which was depressed as the foundryman approached the furnace. The manager of the foundry reported that after these covers were fitted there had been a reduction of 7 kilowatts in the power consumed during normal use of a furnace, the maximum power consumption of which was 35 kilowatts.

(3) A Reverberatory Furnace.-When the main results of the environmental surveys were examined and the various sources of heat loss from furnaces listed, it was possible to propose a broad specification for a furnace which could be used satisfactorily without emitting much "wild heat". It seemed desirable that for cheapness and ease of installation the fuel should be oil or gas; that the metal should, if possible, be heated directly; that the body of the furnace should be adequately insulated to keep the surface temperature below $100^{\circ} \mathrm{F}$; ; that the molten metal should be covered except when metal was being ladled out of the furnace; and that the exhaust gases should be discharged above head level or carried away in ducts.

With such a specification in mind an oil-fired reverberatory furnace was built and has been fully

TABLE 2

THERMAL ENVIRONMENTS NEAR BALE-OUT FURNACES

\begin{tabular}{|c|c|c|c|c|c|}
\hline \multirow{2}{*}{$\begin{array}{c}\text { Type of Bale-out } \\
\text { Furnace }\end{array}$} & \multirow{2}{*}{ Type of Die } & \multirow{2}{*}{$\begin{array}{c}\text { Mean Radiant } \\
\text { Temperature } \\
\left({ }^{\circ} \mathrm{F} .\right)\end{array}$} & \multicolumn{2}{|c|}{ Air Temperature } & \multirow{2}{*}{$\underset{\text { (ft./min.) }}{\text { Air Speed }}$} \\
\hline & & & $\begin{array}{l}\text { Dry Bulb } \\
\left({ }^{\circ} \mathrm{F} .\right)\end{array}$ & $\begin{array}{l}\text { Wet Bulb } \\
\left({ }^{\circ} \mathbf{F} .\right)\end{array}$ & \\
\hline $\begin{array}{c}\text { Conventional } \\
, " \\
, \\
, " \\
, " \\
, " \\
, \\
\text { ", } \\
\text { L.F. electric } \\
\text { Reverberatory } \\
\text {," }\end{array}$ & $\begin{array}{c}\text { Gravity } \\
\text { ", } \\
\text {," } \\
\text { ", } \\
\text {," } \\
\text { ", } \\
\text { Pressure } \\
\text {," } \\
\text { ", } \\
\text { ", }\end{array}$ & $\begin{array}{l}129 \\
151 \\
118 \\
154 \\
145 \\
142 \\
174 \\
144 \\
153 \\
147 \\
131 \\
181 \\
140 \\
135 \\
109 \\
104 \\
111 \\
88\end{array}$ & $\begin{array}{l}90 \\
86 \\
72 \\
88 \\
79 \\
70 \\
82 \\
72 \\
72 \\
75 \\
63 \\
91 \\
84 \\
84 \\
72 \\
68 \\
68 \\
57\end{array}$ & $\begin{array}{l}72 \\
71 \\
55 \\
66 \\
59 \\
58 \\
63 \\
60 \\
62 \\
64 \\
56 \\
64 \\
70 \\
61 \\
57 \\
56 \\
57 \\
49\end{array}$ & $\begin{array}{c}620 \\
170 \\
150 \\
150 \\
300 \\
325 \\
225 \\
\text { No record } \\
90 \\
\text { No record } \\
\text { No record } \\
180 \\
\text { No record } \\
\text { No record } \\
\text { No record } \\
110 \\
50 \\
50\end{array}$ \\
\hline
\end{tabular}


described elsewhere (Turner, Lawrie, Eyden, and Edwards, 1956). Despite early misgivings regarding the metallurgical aspects of this method of melting, it has proved practicable to produce acceptable aluminium castings in both gravity and pressure dies using metal from such furnaces. The thermal efficiency of one of these furnaces was found to be about $32 \%$ compared with $13 \%$ for a conventional furnace.

One furnace of this type has been in continual use for over six months without need of maintenance. The die casters using the furnace said that they preferred it to the conventional type because metal was melted at a greater rate and a high level of metal was thus maintained in the bale-out bath, so that the ladle could be applied obliquely, and the exposure of the die caster to radiation from the metal surface much reduced.

(4) Physiological Heat Stress. - In order to assess the severity of the heat stress imposed upon die casters working near the various types of bale-out furnace, the Belding-Hatch heat stress index has been applied.

In order to compute this index one needs to ascertain the rate at which heat must be lost by the evaporation of sweat if the body is to remain in thermal equilibrium. Hence one needs to know the rate at which the body is producing heat, and to compute the heat exchanges by radiation and convection. Belding and Hatch (1955) give a table showing the metabolic rates associated with various tasks, and they also give equations by means of which the convective and radiative exchanges can be computed on the assumption that the mean skin temperature is $95^{\circ} \mathrm{F}$. The maximum evaporative capacity, under the given conditions of atmospheric humidity and wind speed when the skin is completely wet, is also calculated.

From the figures so obtained the heat-stress index is calculated in two ways. The rate of evaporative heat-loss required to maintain equilibrium is expressed as a percentage (a) of $2,400 \mathrm{~B}$.Th.U. an hour, the rate of heat-loss when 1 litre of sweat is evaporated each hour; and $(b)$ of the maximum rate at which sweat could be evaporated from a completely wet skin. The higher value so obtained is taken as the index of heat stress.
The assumption that the mean skin temperature is invariable at $95^{\circ} \mathrm{F}$. is a drawback of the method, but short of measuring it for every estimation there seems to be no other approach. In the light of present knowledge it is impossible, from a knowledge of the environment and of the metabolic rate, to predict the mean skin temperature with the desirable accuracy. For the wide application of the method in industry there is the disadvantage that the equations apply strictly only to nude men, and estimates of the heat load may be seriously in error if heavy clothing is worn. Belding and Hatch think that no serious error will arise if only single layers of light-weight clothing are worn.

Despite these limitations, however, the index does give a fair quantitative comparison of different environments. Values of the index for two environments which are typical of conditions found near the various furnaces are given in Table 3. Since the foundry workers were clothed the heat stress to which they were subjected would tend to be greater than that indicated.

Belding and Hatch express the meaning of various values of the index in terms of the severity of the effects on persons exposed for eight hours. For values between 50 and 60 they say that there is severe heat strain, and that medical selection of personnel is desirable since the conditions are unsuitable for persons having cardiovascular or respiratory impairments. A comparison of the results given in Table 2 with the first example in Table 3 shows that many of the environments near the conventional type of furnace would fall in this range.

Environments where the value of the index is between 20 and 30 are said to produce only mild heat strain, insufficient to cause significant decrement in the ability to perform muscular work, although there may be substantial decrements in the performance of intellectual tasks in such environments. Thus it would seem that with electric and reverberatory furnaces the heat stress is small in comparison with that caused by the conventional furnaces.

In one foundry, which was typical of many where the conventional oil-fired furnaces were in use, it was possible to measure the sweat losses of a small

TABLE 3

VALUES OF BELDING-HATCH HEAT STRESS INDEX FOR TWO TYPICAL FOUNDRY ENVIRONMENTS

\begin{tabular}{|c|c|c|c|c|c|c|}
\hline \multirow{2}{*}{ Furnace } & \multicolumn{2}{|c|}{ Air Temperature } & \multirow{2}{*}{$\underset{\left({ }^{\circ} \mathbf{F} .\right)}{\text { M.R.T. }}$} & \multirow{2}{*}{$\begin{array}{c}\text { Air Speed } \\
\text { (ft./min.) }\end{array}$} & \multirow{2}{*}{$\begin{array}{c}\text { Globe } \\
\text { Thermometer } \\
\text { Temperature } \\
\left.\text { ( }{ }^{\circ} \mathbf{F} .\right)\end{array}$} & \multirow{2}{*}{$\begin{array}{l}\text { Heat } \\
\text { Stress } \\
\text { Index }\end{array}$} \\
\hline & $\begin{array}{l}\text { Dry Bulb } \\
\left({ }^{\circ} \mathbf{F} .\right)\end{array}$ & $\begin{array}{l}\text { Wet Bulb } \\
\left.\text { ( }{ }^{\circ} \mathbf{F} .\right)\end{array}$ & & & & \\
\hline $\begin{array}{l}\text { Conventional bale-out furnace } \\
\text { L.F. electric and reverberatory furnaces }\end{array}$ & $\begin{array}{l}80 \\
65\end{array}$ & $\begin{array}{l}60 \\
55\end{array}$ & $\begin{array}{l}145 \\
100\end{array}$ & $\begin{array}{r}200 \\
50\end{array}$ & $\begin{array}{r}103 \\
82\end{array}$ & $\begin{array}{l}55 \\
30\end{array}$ \\
\hline
\end{tabular}


sample of the workers. Three men were observed during three shifts. They were weighed both nude and clothed before and after the shift, and they were also weighed clothed before and after each meal break. A careful note was kept of any fluid consumed or excreted in the periods between weighings, and the thermal variables in the environment near each man were measured regularly throughout the shift. The results of these measurements, together with measurements of the thermal environment, are shown in Tables $4 \mathrm{a}$ and $4 \mathrm{~b}$. The rates of sweating which, according to calculation, were needed to maintain thermal equilibrium, are also shown.

When the exposure is not such as to cause considerable quantities of sweat to drip from the body one would expect fair agreement between the calculated and observed rates of sweating, although since the men were clothed the actual rate of sweating might be expected to be somewhat the higher. Averaging the 27 observations on the three men the observed rates of sweating were about $7 \%$ in excess of the estimated required rates. The average deviation of individual observed rates from the predicted requirements was about $24 \%$.

\section{Discussion}

It is apparent from the findings of this survey that conditions in foundries may often be such as to impose a severe heat stress upon those working in them. None of the observations reported here was taken during excessively hot weather; on no occasion did the outside temperature exceed $75^{\circ} \mathrm{F}$. and it was most often between $55^{\circ}$ and $65^{\circ} \mathrm{F}$. Thus it may fairly be inferred that during hot summer weather, with considerable solar radiation falling on the building and a high outside air temperature, working conditions could well become intolerable.

Some alleviation of conditions would doubtless have been possible by the use of radiation shields, and of fans so placed as to increase the air movement over the workers. Both of these methods would have caused some inconvenience and would have done nothing towards reducing the loss of heat from the furnaces.

TABLE $4 \mathrm{a}$

RESULTS OF DETERMINATIONS OF BELDING-HATCH HEAT STRESS INDEX AND OBSERVED AND PREDICTED SWEAT REQUIREMENTS FOR SUBJECT

\begin{tabular}{|c|c|c|c|c|c|c|c|}
\hline Time & $\begin{array}{c}\text { Average } \\
\text { Air } \\
\text { Temperature } \\
\left({ }^{\circ} \mathbf{F} .\right)\end{array}$ & $\begin{array}{c}\text { Average } \\
\text { Water Vapour } \\
\text { Pressure } \\
(\mathrm{mm} . / \mathrm{Hg})\end{array}$ & $\begin{array}{c}\text { Average } \\
\text { Air } \\
\text { Speed } \\
\text { (ft./min.) }\end{array}$ & $\begin{array}{l}\text { Average } \\
\text { M.R.T. } \\
\left({ }^{\circ} \text { F.) }\right.\end{array}$ & $\begin{array}{l}\text { Belding-Hatch } \\
\text { Index }\end{array}$ & $\begin{array}{l}\text { Predicted } \\
\text { Sweat } \\
\text { Requirement } \\
\text { (g./hr.) }\end{array}$ & $\begin{array}{c}\text { Observed } \\
\text { Sweat } \\
\text { Loss } \\
\text { (g./hr.) }\end{array}$ \\
\hline $\begin{array}{l}\text { Day } 1 \\
7-10 \\
10.15-12.30 \\
1-4.30\end{array}$ & $\begin{array}{l}75 \cdot 7 \\
82 \cdot 7 \\
84 \cdot 7\end{array}$ & $\begin{array}{l}12 \cdot 5 \\
12 \\
12\end{array}$ & $\begin{array}{l}170 \\
190 \\
210\end{array}$ & $\begin{array}{l}127 \\
134 \\
132\end{array}$ & $\begin{array}{l}60 \\
69 \\
66\end{array}$ & $\begin{array}{l}590 \\
725 \\
725\end{array}$ & $\begin{array}{l}580 \\
625 \\
470\end{array}$ \\
\hline $\begin{array}{l}\text { Day } 2 \\
7-10 \\
10.15-12.30 \\
1-4.30\end{array}$ & $\begin{array}{l}78 \cdot 4 \\
85 \cdot 7 \\
80 \cdot 8\end{array}$ & $\begin{array}{l}11 \cdot 5 \\
12 \\
13\end{array}$ & $\begin{array}{l}130 \\
120 \\
160\end{array}$ & $\begin{array}{l}118 \\
124 \\
122\end{array}$ & $\begin{array}{l}61 \\
79 \\
64\end{array}$ & $\begin{array}{l}560 \\
690 \\
605\end{array}$ & $\begin{array}{l}635 \\
930 \\
560\end{array}$ \\
\hline $\begin{array}{l}\text { Day } 3 \\
7-10 \\
10.15-12.30 \\
1-4.30\end{array}$ & $\begin{array}{l}81 \cdot 3 \\
81 \cdot 7 \\
84 \cdot 7\end{array}$ & $\begin{array}{l}14 \\
14.5 \\
13.5\end{array}$ & $\begin{array}{r}155 \\
95 \\
140\end{array}$ & $\begin{array}{l}118 \\
118 \\
125\end{array}$ & $\begin{array}{l}64 \\
84 \\
77\end{array}$ & $\begin{array}{l}575 \\
610 \\
680\end{array}$ & $\begin{array}{l}650 \\
650 \\
690\end{array}$ \\
\hline
\end{tabular}

TABLE $4 b$

RESULTS OF DETERMINATION OF BELDING-HATCH HEAT STRESS INDEX AND OBSERVED AND PREDICTED SWEAT REQUIREMENTS FOR SUBJECTS 2 AND 3

\begin{tabular}{|c|c|c|c|c|c|c|c|c|}
\hline \multirow{2}{*}{ Time } & \multirow{2}{*}{$\begin{array}{c}\text { Average } \\
\text { Air } \\
\text { Temperature } \\
\left({ }^{\circ} \mathbf{F} .\right)\end{array}$} & \multirow{2}{*}{$\begin{array}{c}\text { Average } \\
\text { Water Vapour } \\
\text { Pressure } \\
\text { (mm./Hg) }\end{array}$} & \multirow{2}{*}{$\begin{array}{c}\text { Average } \\
\text { Air } \\
\text { Speed } \\
\text { (ft./min.) }\end{array}$} & \multirow{2}{*}{$\begin{array}{c}\text { Average } \\
\text { M.R.T. } \\
\left({ }^{\circ} \mathbf{F} .\right)\end{array}$} & \multirow{2}{*}{$\begin{array}{l}\text { Belding- } \\
\text { Hatch } \\
\text { Index }\end{array}$} & \multirow{2}{*}{$\begin{array}{c}\text { Predicted } \\
\text { Sweat } \\
\text { Requirement } \\
\text { (g./hr.) }\end{array}$} & \multicolumn{2}{|c|}{$\begin{array}{c}\text { Observed Sweat } \\
\text { Loss (g./hr.) }\end{array}$} \\
\hline & & & & & & & Subject 2 & Subject 3 \\
\hline $\begin{array}{l}\text { Day } 1 \\
7-10 \\
10.15-12.30 \\
1-4.30\end{array}$ & $\begin{array}{l}72 \cdot 5 \\
82 \cdot 9 \\
81 \cdot 5\end{array}$ & $\begin{array}{l}12 \cdot 5 \\
12 \\
12\end{array}$ & $\begin{array}{r}85 \\
85 \\
100\end{array}$ & $\begin{array}{l}129 \\
137 \\
131\end{array}$ & $\begin{array}{r}93 \\
105 \\
89\end{array}$ & $\begin{array}{l}660 \\
800 \\
725\end{array}$ & $\begin{array}{l}560 \\
940 \\
780\end{array}$ & $\begin{array}{l}745 \\
935 \\
930\end{array}$ \\
\hline $\begin{array}{l}\text { Day } 2 \\
7-10 \\
10.15-12.30 \\
1-4.30\end{array}$ & $\begin{array}{l}78 \cdot 3 \\
86 \cdot 9 \\
87 \cdot 4\end{array}$ & $\begin{array}{l}11 \cdot 5 \\
12 \\
13\end{array}$ & $\begin{array}{r}95 \\
100 \\
145\end{array}$ & $\begin{array}{l}116 \\
133 \\
123\end{array}$ & $\begin{array}{l}70 \\
97 \\
76\end{array}$ & $\begin{array}{l}565 \\
790 \\
690\end{array}$ & $\begin{array}{l}710 \\
840 \\
775\end{array}$ & $\begin{array}{l}690 \\
590 \\
740\end{array}$ \\
\hline $\begin{array}{l}\text { Day } 3 \\
7{ }^{-10} \\
10.15-12.30 \\
1-4.30\end{array}$ & $\begin{array}{l}83 \cdot 3 \\
86 \cdot 8 \\
87 \cdot 3\end{array}$ & $\begin{array}{l}14 \\
14 \cdot 5 \\
13 \cdot 5\end{array}$ & $\begin{array}{r}75 \\
120 \\
135\end{array}$ & $\begin{array}{l}112 \\
116 \\
123\end{array}$ & $\begin{array}{l}86 \\
78 \\
80\end{array}$ & $\begin{array}{l}580 \\
625 \\
690\end{array}$ & $\begin{array}{l}500 \\
865 \\
670\end{array}$ & $\begin{array}{l}650 \\
740 \\
805\end{array}$ \\
\hline
\end{tabular}


A notable example of the ameliorative effect of increased ventilation was seen in one foundry in which there was a row of furnaces used for melting a magnesium alloy. Dense fumes are emitted from molten magnesium, particularly when flux is added. Very lavish exhaust ventilation had been applied to the furnaces to remove the fumes, and as a result the total volume of air removed from the foundry was so great that the air temperature was little above that outside. Although the radiation intensity was similar to that in foundries where aluminium was melted, but where such lavish exhaust ventilation was not considered to be essential, the subjective impression was of a much more comfortable working environment.

It has been shown during this study that it is possible in the design of equipment to exclude the sources of waste heat to a large extent, thereby achieving a much more efficient use of fuel. The capital cost of the reverberatory furnace referred to earlier compared favourably with that of the conventional type of bale-out furnace; the maintenance costs were much less because there was no crucible to be replaced regularly, and the fuel consumption was much reduced. It thus seems that the replacement of inefficient furnaces would result not only in better working conditions, but also in a considerable reduction of running costs.

\section{Summary}

A study has been made of the thermal environment in positions typically occupied by foundrymen in non-ferrous foundries.

Two groups of tasks were studied, one involving short exposures to intense heat, the other involving exposure to a hot environment continuously throughout the shift. Measurements are given of thermal radiation intensities during the short exposures to which the furnacemen were subjected when the furnace door was opened. In the longer exposures, measurements are given for conventional oil-fired furnaces, a low-frequency induction electrical furnace, and a reverberatory oil-fired furnace.

In order to assess the severity of heat stress imposed upon die casters working near various types of bale-out furnaces, Belding-Hatch heat stress indices were calculated for three workers over three shifts. Attention is drawn to the limitations inherent in this index.

In one foundry, actual sweat losses of a small sample of the workers were measured and compared with the predicted rates of sweat loss. The observations showed that conditions in foundries, particularly where conventional oil- or gas-fired furnaces were used, were often such as to impose severe heat stress upon the workers. An example is given of the ameliorative effects of increased exhaust ventilation.

Much less thermal radiation was produced by the reverberatory furnace than by conventional types of furnace. It is concluded that the replacement of the less efficient conventional furnaces would not only result in better working conditions, but also in a considerable reduction in running costs.

The author wishes to express his indebtedness to Dr. T. Bedford, Director, M.R.C. Environmental Hygiene Research Unit, for permission to take part in this survey and for his continued interest and encouragement; to Mr. W. B. Lawrie, H.M. Engineering Inspector of Factories, for his valuable cooperation in planning the survey and in taking the observations; and to the many persons in the industry who, by their help, made the study possible.

\section{REFERENCES}

Belding, H. S., and Hatch, T. F. (1955). Index for Evaluating Heat Stress in Terms of Resulting Physiological Strains. Heat, Pip., Air Condit., 27, Aug., p. 129.

Turner, D., Lawrie, W. B., Eyden, A., and Edwards, A. (1956). 